\title{
2D-immunoblotting analysis of Sporothrix schenckii cell wall
}

\author{
Estela Ruiz-Baca ${ }^{1 /+}$, Héctor M Mora-Montes², Everardo López-Romero², \\ Conchita Toriello³, Virgilio Mojica-Marín', Norma Urtiz-Estrada'
}

\author{
'Facultad de Ciencias Químicas, Universidad Juárez del Estado de Durango, Durango, México \\ ${ }^{2}$ Departamento de Biología, División de Ciencias Naturales y Exactas, Universidad de Guanajuato, Guanajuato, México \\ ${ }^{3}$ Departamento de Microbiología y Parasitología, Facultad de Medicina, Universidad Nacional Autónoma de México, Distrito Federal, México
}

We utilized two-dimensional gel electrophoresis and immunoblotting (2D-immunoblotting) with anti-Sporothrix schenckii antibodies to identify antigenic proteins in cell wall preparations obtained from the mycelial and yeast-like morphologies of the fungus. Results showed that a 70-kDa glycoprotein (Gp70) was the major antigen detected in the cell wall of both morphologies and that a 60-kDa glycoprotein was present only in yeast-like cells. In addition to the Gp70, the wall from filament cells showed four proteins with molecular weights of 48, 55, 66 and $67 \mathrm{kDa}$, some of which exhibited several isoforms. To our knowledge, this is the first $2 D$-immunoblotting analysis of the S. schenckii cell wall.

Key words: sporotrichosis - Sporothrix schenckii - cell wall - glycoproteins - 2D-immunoblotting analysis

The dimorphic fungus Sporothrix schenckii is the etiological agent of sporotrichosis, an endemic subcutaneous mycosis in Latin America, whose prevalence has significantly increased during the last few years mainly in immunocompromised patients (Callens et al. 2006, Lopes-Bezerra et al. 2006). The S. schenckii cell wall is composed of alkali-soluble and insoluble glucans, which are found in both morphological phases of the fungus (Previato et al. 1979, Lopes-Bezerra et al. 2006). Despite significant progress in the knowledge of structural polysaccharides, little is known regarding the identity and characteristics of cell wall proteins. Thus far, a peptide-rhamnomannan and peptide-rhamnogalactan have been isolated and characterized from wall preparations of yeast-like cells (Lloyd \& Bitoon 1971, Nakamura 1976, Lopes-Bezerra et al. 2006). In addition, there are some reports dealing with the role of a cell wall glycoprotein of $70 \mathrm{kDa}$ in adhesion of $S$. schenckii to host tissues and extracellular matrix components as well as fungal pathogenesis (Nascimento et al. 2008, Ruiz-Baca et al. 2009, Teixeira et al. 2009).

2D-immunoblotting analysis has become one of the most frequently used tools to search antigens present in fungal pathogens such as Candida albicans, Cryptococcus neoformans and Aspergillus fumigatus (Pitarch et al. 2002, 2009, Gautam et al. 2007, Young et al. 2009). This approach was used here to further advance in the identification of antigenic proteins present in the cell wall

Financial support: UJED

HMMM was supported by CONACyT (117063).

+ Corresponding author: erb750@hotmail.com

Received 7 August 2010

Accepted 16 December 2010 of both morphologies of $S$. schenckii. Antibodies raised against the whole fungal cell allowed the identification of morphology-specific cell wall glycoproteins as well as glycoproteins present in both fungal phases.

Organism and culture conditions - S. schenckii ATCC 58251 was used in this study. For mycelia propagation, 2-1 Erlenmeyer flasks containing $600 \mathrm{~mL}$ of YPG medium $(0.3 \%$ yeast extract, $1 \%$ peptone and $2 \%$ glucose, $\mathrm{pH} 4.5)$ were inoculated with $1 \times 10^{6}$ conidia $\mathrm{mL}^{-1}$ and incubated for $24 \mathrm{~h}$ at $28^{\circ} \mathrm{C}$ with shaking $(120$ $\mathrm{rpm})$. To obtain the yeast-like form, the $\mathrm{pH}$ of the medium was adjusted to 7.2 and the flasks were shaken for six days at $37^{\circ} \mathrm{C}$. Hyphae were collected by filtration in a Büchner filter and yeast-like cells were harvested by centrifugation at 7,000 $\mathrm{g}$ for $10 \mathrm{~min}$. In both cases, cells were washed twice with lysis buffer $(50 \mathrm{mM}$ Tris- $\mathrm{HCl}$ buffer, $\mathrm{pH} 7.5$, supplemented with $1 \mathrm{mM}$ phenylmethylsulfonyl fluoride).

Extraction of cell wall proteins - Mycelia and yeastlike cells were resuspended in $10 \mathrm{~mL}$ of lysis buffer and disrupted in an MSK cell homogenizer (Braun Melsungen, Germany) as described previously (Mora-Montes et al. 2010). To isolate cell walls, the cell homogenate was centrifuged for $15 \mathrm{~min}$ at $1,300 \mathrm{~g}$ and $4^{\circ} \mathrm{C}$ and the pellet was saved and washed five times with lysis buffer to eliminate any intracellular component associated with the walls during the cell disruption process. Cell wall proteins were extracted with hot $2 \%$ sodium dodecyl sulfate (SDS) as previously described (Ruiz-Baca et al. 2009). Proteins were precipitated with $70 \%(\mathrm{v} / \mathrm{v})$ ethanol at $-20^{\circ} \mathrm{C}$ for $5 \mathrm{~h}$ and kept at $-70^{\circ} \mathrm{C}$ until use. Protein concentration was determined by the Bradford method (1976).

Two-dimensional polyacrylamide gel electrophoresis (2D-PAGE) - Samples containing $80 \mu \mathrm{g}$ of protein were cleaned with the ReadyPrep ${ }^{\mathrm{TM}} 2 \mathrm{D}-\mathrm{Cleanup}$ kit (Bio-Rad) following the manufacturer's instructions, solubilized in $125 \mu \mathrm{L}$ of rehydration buffer (7 M urea, $2 \mathrm{M}$ thiourea, 4\% CHAPS, 20 mM DTT, 0.5\% ampholytes and 0.002\% 
bromophenol blue) and applied onto Immobiline $\mathrm{pH}$ 4-7 non-linear DryStrips (7 cm long, Bio-Rad). Strips were rehydrated for $16 \mathrm{~h}$ before isoelectric focusing (IEF). IEF was performed with a Protean IEF Cell (Bio-Rad) at $20^{\circ} \mathrm{C}$ using the following conditions: $250 \mathrm{~V}$ for $15 \mathrm{~min}$, $250-4,000 \mathrm{~V}$ for $2 \mathrm{~h}$ and $4,000 \mathrm{~V}$ until complete 10,000 $\mathrm{V} / \mathrm{h}$. After IEF, strips were sequentially equilibrated for $15 \mathrm{~min}$ each in the equilibrium solution $(50 \mathrm{mM}$ Tris$\mathrm{HCl}, \mathrm{pH} 8.8,6 \mathrm{M}$ urea, $30 \%$ glycerol, $2 \%$ SDS, $0.5 \%$ DTT and $2 \%$ iodoacetamide) with constant agitation. For the second dimension, IEF strips were placed on top of a $10 \%$ vertical SDS-PAGE gel and covered with $0.5 \%$ agarose. Proteins were separated for $1 \mathrm{~h}$ at $90 \mathrm{~V}$ in a Mini-PROTEAN 3 Cell unit (Bio-Rad) and either silver stained (Merril 1990) or transferred to nitrocellulose membranes. Images were captured using an Image Scanner (Bio-Rad) and analyzed with the PDQuestTM 2-D analysis software (Bio-Rad). Assays were repeated at least thrice using independent cell wall preparations.

Antibodies - Anti-S. schenckii antibodies were raised in a New Zealand male rabbit following the immunization scheme described by Toriello and Mariat (1974). Briefly, $1 \mathrm{~mL}$ aliquots containing $1 \times 10^{8}$ formaldehydekilled yeast-like cells were inoculated into the marginal ear vein of the animal three times per week for two weeks and one week after the final injection the rabbit was bled. The blood serum was saved and stored at $-70^{\circ} \mathrm{C}$ in aliquots of $2 \mathrm{~mL}$ containing $0.01 \%(\mathrm{w} / \mathrm{v})$ sodium azide.

Immunoblotting assays - Immunodetection was carried out as previously described (Mora-Montes et al. 2008), except that a primary polyclonal anti-S. schenckii antibody diluted 1:500 in phosphate buffered salineTween $20(0.05 \%)$ was used.

Glycoprotein staining - Proteins transferred to nitrocellulose membranes after 2D-PAGE were stained with periodic acid-Schiff (PAS) reagent as described previously (Ruiz-Baca et al. 2009).

Extraction of cell walls with hot SDS rendered significantly more protein from yeast-like cells $(2.1 \pm 0.02$ $\mu \mathrm{g}$ per mg of cell wall dry weight) than from mycelia (1.2 $\pm 0.03 \mu \mathrm{g}$ per $\mathrm{mg}$ of cell wall dry weight). Silver staining after 2D-PAGE revealed a higher number of proteins extracted from hyphal walls (Fig. 1A) than from yeast walls (Fig. 1C) (130 vs. 115 protein spots, respectively). A 70$\mathrm{kDa}$ protein showing several isoforms in a $\mathrm{pI}$ range from 4-5 was immunodetected in extracts of walls from both morphologies (Fig. 1B, D). In addition, hyphal walls presented proteins with molecular masses of 48, 55, 66 and $67 \mathrm{kDa}$ (Fig. 1B). Moreover, a 60-kDa protein with several isoforms in a pI range from 5-6 was immunorecognized only in yeast walls (Fig. 1D). To determine whether some of the immunodetected proteins were glycosylated, the 2D-PAGE gels were stained with PAS reagent. Results indicated that both the 60 and $70-\mathrm{kDa}$ proteins present in yeast walls were glycoproteins and that the former was present only in extracts of hyphal walls (Fig. 2). It should be noted that the presence of other glycoproteins in the morphological phases of the fungus cannot be ruled out as the methodology used here detects only proteins with a rather high degree of glycosylation.
The antigenic composition of both morphologies of S. schenckii is poorly understood and there are only a few described antigens consisting mainly of glycoproteins with a high degree of glycosylation, containing mannose, rhamnose and galactose. The sugar composition of glycoproteins varies with the culture age and is closely related to the growth morphology of the organism (Takata \& Ishizaki 1983). Scott and Muchmore (1989) demonstrated that yeast-like cells of $S$. schenckii contain two proteins of 40 and $70-\mathrm{kDa}$ as the major antigens recognized by sera obtained from sporotrichosis patients; also, it was demonstrated that sera from S. schenckiiinfected mice reacted mainly with a $70-\mathrm{kDa}$ antigen (Nascimento \& Almeida 2005). In addition, we have purified and characterized a 70-kDa glycoprotein (Gp70) from the cell wall of $S$. schenckii yeast-like cells that exhibited adhesion properties (Ruiz-Baca et al. 2009). Blotting with a polyclonal anti-Gp70 serum revealed a single spot with a pI of 4.1, which suggested that Gp70 is a $S$. schenckii-specific protein as it was not immunodetected in other pathogenic and non-pathogenic fungi (Ruiz-Baca et al. 2009). Similar studies have not been carried out in the filamentous phase. Almeida-Paes et al. (2007) identified five exoantigens of 42, 51, 63, 70 and
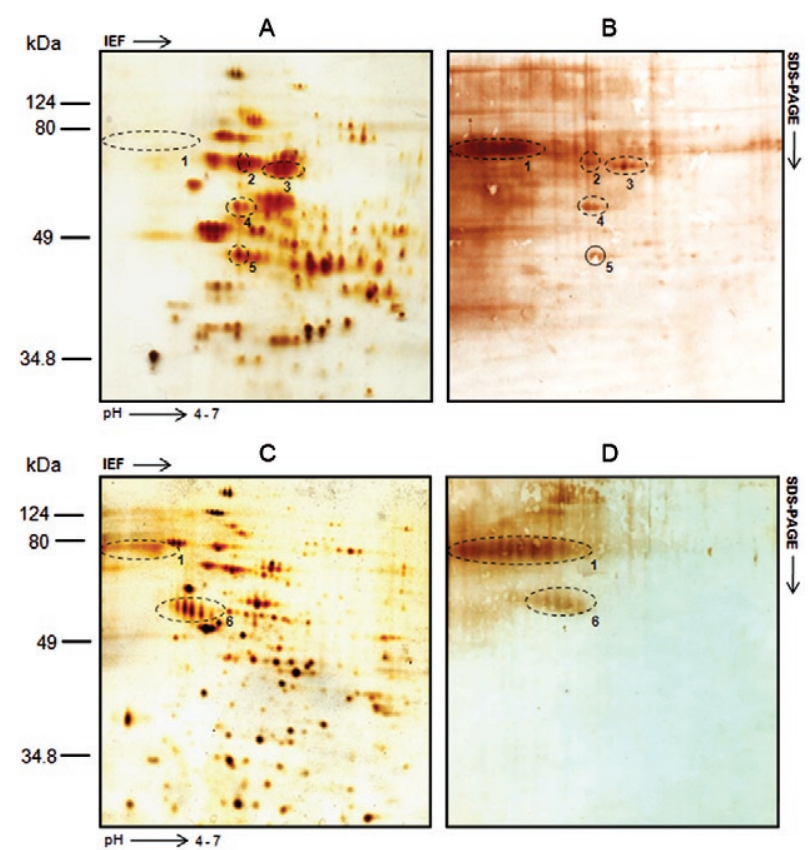

Fig. 1: two-dimensional polyacrylamide gel electrophoresis (2DPAGE) of Sporothrix schenckii cell wall proteins. Proteins $(80 \mu \mathrm{g})$ extracted with hot sodium dodecyl sulphate (SDS) from hyphal (A, B) and yeast-like (C, D) cell walls were separated by 2D-PAGE as described in the text. Numbered broken circles represent antigens showing several isoforms revealed either by silver staining $(\mathrm{A}, \mathrm{C})$ or by immunoblotting (B, D). Antigens detected in hyphal cell walls were: 1, 70 kDa (pI's 4-5); 2, 67 kDa (pI's 5.3, 5.4); 3, 66 kDa (pI's 5.7, 5.8, $5.9) ; 4,55 \mathrm{kDa}$ (pI's 5.2, 5.3); 5, $48 \mathrm{kDa}$ (pI 5.4). Antigens detected in yeast-like cell walls were: $1,70 \mathrm{kDa}$ (pI's 4-5); 6, $60 \mathrm{kDa}$ (pI 4.5-5.1). The position of molecular weight standards are indicated on the left. IEF: isoelectric focusing. 


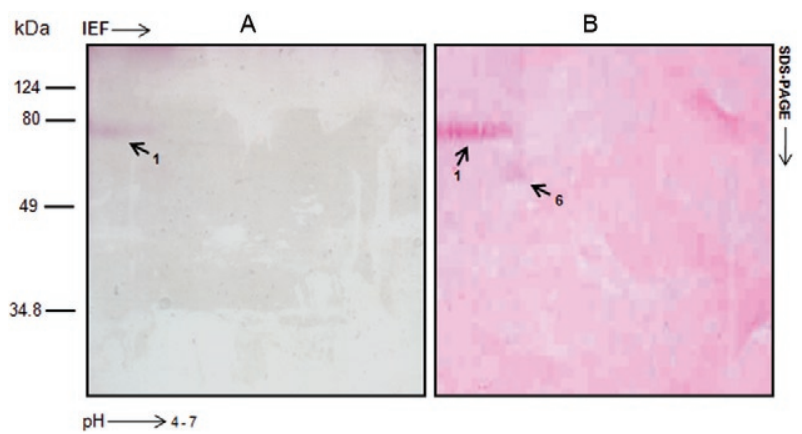

Fig. 2: periodic acid-Schiff (PAS) staining of Sporothri schenckii cell wall glycoproteins. Proteins $(80 \mu \mathrm{g})$ extracted with hot sodium dodecyl sulphate (SDS) from mycelial (A) and yeast-like (B) cells were separated by two-dimensional polyacrylamide gel electrophoresis (PAGE), transferred to nitrocellulose membranes and stained with the PAS reagent. 1, 70-kDa glycoprotein (pI's 4-5); 6, 60-kDa glycoprotein ( $\mathrm{pI}$ 4.5-5.1). The position of molecular weight standards is indicated on the left. IEF: isoelectric focusing.

$90 \mathrm{kDa}$ in Sabouraud dextrose cultures of mycelial cells of $S$. schenckii 23508 , with the 51 and $63 \mathrm{kDa}$ antigens being the most prominent. Optimum expression of these components occurred in the stationary phase of growth. Here, five antigens of 48, 55, 66, 67 and $70 \mathrm{kDa}$ were immunodetected in the mycelial phase of S. schenckii ATCC 58251 , whereas only two antigens of 60 and $70 \mathrm{kDa}$ were identified in yeast cells. Because mycelial cell antigens have not been purified or characterized, more studies will be necessary to verify if these are related to those previously reported and to determine their presence in other fungal strains. The observed differences between yeast and mycelial cells in terms of the proteins detected in this study may result from the physicochemical nature of the proteins obtained from each form. The amount of acidic and basic proteins in the two morphologies may be different, with the mycelial phase containing more proteins resolved within the $\mathrm{pH}$ 4-7 range (Fig. 1A).

In summary, the Gp70 was the major antigenic protein present in the walls of both fungal morphologies and this may correspond to the previously characterized Gp70. As the $S$. schenckii genome has not been yet sequenced, 2Dimmunoblotting studies focused on surface antigens can help to understand many of the molecular aspects that govern the biology of the fungus and sporotrichosis.

\section{ACKNOWLEDGEMENTS}

To Bertha C Calderón Barraza, for technical assistance.

\section{REFERENCES}

Almeida-Paes R, Pimenta MA, Pizzini CV, Monteiro PC, Peralta JM, Nosanchuk JD, Zancopé-Oliveira RM 2007. Use of mycelialphase Sporothrix schenckii exoantigens in an enzyme-linked immunosorbent assay for diagnosis of sporotrichosis by antibody detection. Clin Vaccine Immunol 14: 244-249.

Bradford MM 1976. A rapid and sensitive method for the quantitation of microgram quantities of protein utilizing the principle of protein-dye binding. Anal Biochem 72: 248-254.

Callens SF, Kitetele F, Lukun P, Lelo P, Van Rie A, Behets F, Colebunders R 2006. Pulmonary Sporothrix schenckii infection in a HIV positive child. J Trop Pediatr 52: 144-146.
Gautam P, Sundaram CS, Madan T, Gade WN, Shah A, Sirdeshmukh R, Sarma PU 2007. Identification of novel allergens of Aspergillus fumigatus using immunoproteomics approach. Clin Exp Allergy 37: 1239-1249.

Lloyd KO, Bitoon MA 1971. Isolation and purification of a peptidorhamnomannan from the yeast form of Sporothrix schenckii. Structural and immunochemical studies. J Immunol 107: 663-671.

Lopes-Bezerra LM, Schubach A, Costa RO 2006. Sporothrix schenckii and sporotrichosis. An Acad Bras Cienc 78: 293-308.

Merril CR 1990. Gel-staining techniques. Methods Enzymol 182: 477-488.

Mora-Montes HM, López-Romero E, Zinker S, Ponce-Noyola P, Flores-Carreón A 2008. Heterologous expression and biochemical characterization of an 1,2 -mannosidase encoded by the Candida albicans MNS1 gene. Mem Inst Oswaldo Cruz 103: 724-730.

Mora-Montes HM, Robledo-Ortiz CI, González-Sánchez LC, LópezEsparza A, López-Romero E, Flores-Carreón A 2010. Purification and biochemical characterisation of endoplasmic reticulum a1,2-mannosidase from Sporothrix schenckii. Mem Inst Oswaldo Cruz 105: 79-85.

Nakamura Y 1976. Purification and isolation of a biologically active peptido-rhamnogalactan from Sporothrix schenckii. J Dermatol 3: 25-29.

Nascimento RC, Almeida SR 2005. Humoral immune response against soluble and fractionate antigens in experimental sporotrichosis. FEMS Immunol Med Microbiol 43: 241-247.

Nascimento RC, Espíndola NM, Castro RA, Teixeira PA, Loureiro y Penha CV, Lopes-Bezerra LM, Almeida SR 2008. Passive immunization with monoclonal antibody against a $70-\mathrm{kDa}$ putative adhesin of Sporothrix schenckii induces protection in murine sporotrichosis. Eur J Immunol 38: 3080-3089.

Pitarch A, Nombela C, Gil C 2009. Proteomic profiling of serologic response to Candida albicans during host-commensal and hostpathogen interactions. Methods Mol Biol 470: 369-411.

Pitarch A, Sánchez M, Nombela C, Gil C 2002. Sequential fractionation and two-dimensional gel analysis unravels the complexity of the dimorphic fungus Candida albicans cell wall proteome. Mol Cell Proteomics 1: 967-982.

Previato JO, Gorin PAJ, Haskins RH, Travassos LR 1979. Soluble and insoluble glucans from different cell types of the human pathogen Sporothrix schenckii. Exp Mycol 3: 92-105.

Ruiz-Baca E, Toriello C, Perez-Torres A, Sabanero-Lopez M, Villagomez-Castro JC, Lopez-Romero E 2009. Isolation and some properties of a glycoprotein of $70 \mathrm{kDa}(\mathrm{Gp} 70)$ from the cell wall of Sporothrix schenckii involved in fungal adherence to dermal extracellular matrix. Med Mycol 47: 185-196.

Scott EN, Muchmore HG 1989. Immunoblot analysis of antibody responses to Sporothrix schenckii. J Clin Microbiol 27: 300-304.

Takata M, Ishizaki H 1983. Correlations among culture times, sugar composition and biological activities of Sporothrix schenckii antigens. Mycopathologia 84: 31-39.

Teixeira PA, de Castro RA, Nascimento RC, Tronchin G, Torres AP, Lazéra M, de Almeida SR, Bouchara JP, Loureiro y Penha CV, Lopes-Bezerra LM 2009. Cell surface expression of adhesins for fibronectin correlates with virulence in Sporothrix schenckii. Microbiology 155: 3730-3738.

Toriello C, Mariat F 1974. Etude comparée des polyosides des champignons Ceratocystis stenoceras et Sporothrix schenckii. Composition chimique et analyse immunologique. Ann Microbiol (Paris) 125A: 287-307.

Young M, Macias S, Thomas D, Wormley FL Jr 2009. A proteomicbased approach for the identification of immunodominant Cryptococcus neoformans proteins. Proteomics 9: 2578-2588. 